\title{
PHOTOSYNTHETIC PRODUCTION OF WHEAT UNDER PRECISION PLANTING PATTERNS IN NORTHERN CHINA
}

\author{
PRODUÇÃO FOTOSSINTÉTICA DE TRIGO ATRAVÉS DE PADRÕES DE \\ PLANTAÇÃO DE PRECISÃO NO NORTE DA CHINA
}

\author{
Zhen ZHANG ${ }^{1,2}$; Xiang Min MAO ${ }^{1}$; Wen Wen ZHONG ${ }^{2}$; Zhi Bo FENG ${ }^{2}$; Xun Bo ZHOU ${ }^{1}$ \\ 1. Guangxi Colleges and Universities Key Laboratory of Crop Cultivation and Farming System, Agricultural College of \\ Guangxi University, Nanning, 530004 China. whyzxb@gmail.com; 2. College of Agronomy, Shandong Agricultural \\ University, Tai' an, 271018 China; Z. ZHANG and X. M. MAO are co-first author.
}

\begin{abstract}
Winter wheat (Triticum aestivum) is cultivated across a wide region; however, water is scarce during the growing season of wheat in the Northern Plain of China. Therefore, winter wheat should be irrigated to maintain a stable and high grain yield. The aim of this field study was to develop a water-conserving precision planting pattern for winter wheat that is grown in the Northern China Plain with the purpose of exploring the benefits in maintaining water and effects on wheat productivity. To accomplish this, several production variables and photosynthetic indexes were measured, including the number of stems, the leaf area index (LAI), photosynthetically available radiation (PAR), net photosynthetic rate, and grain yield. The study was carried out during the 2011-2012 and 2012-2013 winter wheat growing seasons. The experiment included a double-row planting pattern (DRPP) and a single-row planting pattern (SRPP), both of which were either irrigated or rainfed. The area of each plot was $9 \mathrm{~m}^{2}$, and the experimental design was a randomized blocks design with three replicates. All results were analyzed with an ANOVA, the F test, and the LSD ( $\mathrm{p} \leq 0.05)$ for means comparison. PAR capture ratios in the DRPP were higher than those in the SRPP at 50-120 cm above the ground. The photosynthetic traits of flag leaves under irrigated conditions were not significantly influenced by the respective planting pattern. However, at a growth stage of 80 under the rainfed conditions, the mean photosynthetic rate within flag leaves in the DRPP was higher than that in the SRPP. Furthermore, the DRPP under rainfed conditions was more likely to increase the apparent quantum yield (AQY) of flag leaves than the yield obtained under irrigation. These results suggest that DRPP optimizes the canopy PAR distribution in winter wheat and contributes to the maintenance of a higher photosynthetic capacity in the flag leaves under water stress (the rainfed condition). This relationship may be applied in demonstration trials to encourage winter wheat farmers to incorporate the use of DRPP in the drought-prone areas, which are subjected to insufficient precipitation during the growing stage of wheat in Northern China.
\end{abstract}

KEYWORDS: Triticum aestivum. Photosynthetic active radiation (PAR) capture ratio. Net photosynthetic rate. Leaf area index. Yield components.

\section{INTRODUCTION}

Wheat (Triticum aestivum) is an important food crop in Northern China. An uneven spatial and temporal distribution of precipitation makes wheat vulnerable to water deficits during growing development (DENG et al., 2006; ZHOU et al., 2015). The Tai' an region receives precipitation that reaches a maximum level of $200 \mathrm{~mm}$ in the growing season of winter wheat. However, this precipitation does not satisfy the requirements of the winter wheat (SACKS et al., 2010). Therefore, it is important to develop methods to better maintain the available water for the crop population, which determines the wheat yield. Both water pollution and water level declines in North China have increased in severity, and water shortages can limit agricultural production. Rampino et al. (2006) indicated that the insufficient availability of water is a serious environmental concern and poses a limitation for the normal growth, development, and yield of crops.
With the goal of solving the serious water deficits in the agricultural regions of Northern China, an increasingly greater number of drought-resistant winter wheat varieties are being cultivated (DONG et al., 2011). Meanwhile, cultivation methods have become increasingly more relevant in dealing with drought. Row spacing is an agronomic practice that affects the canopy structure, light interception, radiation use efficiency, and biomass production in some plants (ACRECHE et al., 2009; MATTERA et al., 2013). The main factors that influence plant growth include light, water, nutrients, and weed competition (BRANT et al., 2009). Appropriate row spacing affects the grain yield by improving the crop population, light distribution, and the relative humidity in the field. Interplant competition will occur when the supply of a single element for growth decreases to a level below the average level of plant groups in the field (AVOLA et al., 2008). If seeds are near enough to each other when they are sown, plants can influence one another and subsequently affect the atmospheric or soil 
environment, thereby decreasing growth rates (DE BRUIN; PEDERSEN, 2008). Lack et al. (2012) revealed that planting patterns and drought stress had very significant effects on yields of corn.

In the field, the growth of a crop is related to the photosynthetically available radiation (PAR) capture ratio by the canopy (GITELSON et al., 2015). Dry matter accumulation can occur on the ground when leaves intercept incoming photosynthetically available radiation (PAR) (FENG et al., 2014). Stomatal closure is one of the first responses to drought stress, by limiting $\mathrm{CO}_{2}$ absorption, and decreases photosynthetic activity (NAYYAR; GUPTA, 2006). The changes in stomatal gas exchange rates and chlorophyll fluorescence provide information on most components of photosynthetic activity and plant responses to environmental factors such as drought stress (PANDA et al., 2008), which results in different rates of leaf photosynthesis at the grain ripening stage (SAN-OH et al., 2006).

The objectives of this study on winter wheat (Triticum aestivum L.) were to assess the effects of a double-row planting pattern (DRPP) relative to a single-row planting pattern (SRPP) at different water conditions on both photosynthetic characteristics and products including stem numbers,
LAI, PAR, yield components, and grain yield. The ultimate goal was to develop a new winter wheat water-conserving pattern in Northern China.

\section{MATERIAL AND METHODS}

The two-year study was conducted at the Agronomy Experimental Station of Shandong Agricultural University during the 2011-2012 and 2012-2013 winter wheat growing seasons. The experimental site $\left(36^{\circ} 10^{\prime} 19^{\prime \prime} \mathrm{N}, 117^{\circ} 9^{\prime} 03^{\prime \prime} \mathrm{E}\right)$ is located in Tai' an, the main winter cultivating region of the Northern Plain in China. The total precipitation and solar radiation in the growing seasons of the winter wheat (from sowing to harvesting) were, respectively, $205.8 \mathrm{~mm}$ and 2803 $\mathrm{MJ} \mathrm{m}^{-2}$ in 2011-2012 and $195.8 \mathrm{~mm}$ and $2961 \mathrm{MJ}$ $\mathrm{m}^{-2}$ in 2012-2013. The precipitation during the winter wheat growing season is shown in Table 1 . The total value of accumulated degree units $\left(\geq 0^{\circ} \mathrm{C}\right)$ during the growing season for 2011-2013 was $2505.9^{\circ} \mathrm{C}$, and the frost-free period was 193 days. Weather data were obtained from the Tai'an Agrometeorological Experimental Station, which was located $500 \mathrm{~m}$ from the experimental site.

Table 1. Monthly precipitation $(\mathrm{mm})$ during the winter wheat growing season.

\begin{tabular}{lllllllllll}
\hline Years & $\begin{array}{l}\text { Oct. } \\
\text { (Sowing) }\end{array}$ & Nov. & Dec. & Jan. & Feb. & Mar. & Apr. & May & $\begin{array}{l}\text { Jun. } \\
\text { (Harvest) }\end{array}$ & Total \\
\hline $2011-2012$ & 13.4 & 99.2 & 14.7 & 1.8 & 0.1 & 25.9 & 43.7 & 7.0 & 0.0 & 205.8 \\
$2012-2013$ & 15.7 & 18.4 & 19.0 & 5.1 & 13.2 & 13.6 & 12.8 & 98.0 & 0.0 & 195.8 \\
\hline
\end{tabular}

The experimental site in the $0-20-\mathrm{cm}$ soil layer is characterized by silt loam soil with a soil organic matter content of $16.2 \mathrm{~g} \mathrm{~kg}^{-1}$, a total $\mathrm{N}$ content of $1.3 \mathrm{~g} \mathrm{~kg}^{-1}$, an available $\mathrm{K}$ content of 95 $\mathrm{mg} \mathrm{kg}^{-1}$, and an available $\mathrm{P}$ content of $35 \mathrm{mg} \mathrm{kg}^{-1}$ at $\mathrm{pH}$ 6.9. Before sowing, $26.1 \mathrm{~g} \mathrm{~m}^{-2}$ of diammonium hydrogen phosphate, $38.4 \mathrm{~g} \mathrm{~m}^{-2}$ of urea, and $21.0 \mathrm{~g}$ $\mathrm{m}^{-2}$ of potassium sulfate were applied to the soil; half of the total nitrogen (urea) was applied as a base fertilizer before sowing and topdressing in the growth stage GS 30 (the stem elongation stage, ZADOKS et al., 1974).

The experimental design included complete randomized blocks with three replicates. Each experimental plot unit was $3 \mathrm{~m} \times 3 \mathrm{~m}$; to prevent the lateral flow of soil water each plot was separated by concrete slabs that were $2 \mathrm{~m}$ in depth and $15 \mathrm{~cm}$ in width. The structure was buried on all four sides in the field. The treatments were consisted of two planting patterns (SRPP and DRPP; Figure 1) and two water conditions (I, irrigated; R, rainfed). Under the irrigation condition, $60 \mathrm{~mm}$ of water was applied on each of the following dates: April 8, May 3, and May 1 in 2012 and April 6, May 3, and May 15 in 2013. The amount of water was measured by a flow meter. Winter wheat (variety Jimai 22) was handsown at a density of 200 plants $\mathrm{m}^{-1}$ on October 8 , 2011, and October 10, 2012. Crops were harvested on June 13, 2012, and June 8, 2013. 
Photosynthetic production...

ZHANG, Z. et al.

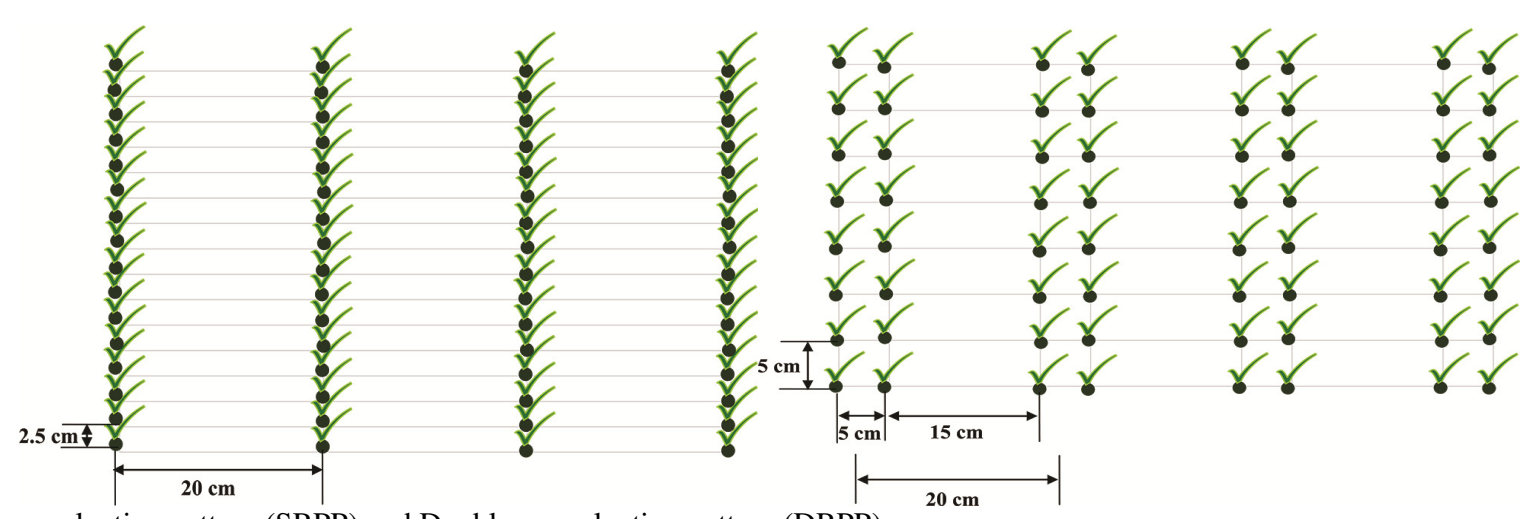

Single-row planting pattern (SRPP) and Double-row planting pattern (DRPP)

Figure 1. Schematic diagram showing the precision planting patterns.

The stem number was determined in a $1 \mathrm{~m}^{2}$ quarter in each plot at the following growth stages (GS): 20, 28, 32, 35, 45, and 80. Twenty plants per replicate were sampled randomly at the harvest to determine yield components. The following equation was used to calculate the LAI at GS45, GS49, GS71, and GS80:

leaf area $=$ leaf length $\times$ leaf width $\times 0.78$

At GS45, GS49, GS71, and GS80, radiation and leaf gas exchanges (net photosynthetic rate, Pn; intercellular $\mathrm{CO}_{2}$ concentration, $\mathrm{Ci}$; transpiration rate, $\mathrm{Tr} ; \mathrm{H}_{2} \mathrm{O}$ conductance, Cond; apparent quantum yield, AQY) were measured. The canopy radiation, reflection, and underlying radiation were measured aboveground at 0,50 , and $120 \mathrm{~cm}$, using a SunScan Canopy Analysis System (Delta T Devices Ltd., UK). PAR values exceeding $700 \mu \mathrm{mol} \mathrm{m} \mathrm{m}^{-2} \mathrm{~s}^{-1}$ were measured using a $1.5-\mathrm{m}$ long linear sensor placed between the rows and parallel to each other.

The photosynthetic rate and diffusion conductance in flag leaves were determined using a portable infrared gas analyzer (LI-6400; LI-COR Inc., USA) on a clear day from 9 a.m. to 11 a.m. (after the photoperiod began). The diffusion conductance was calculated according to Liu et al. (2015). The quantum flux density (QFD) on a leaf surface, relative humidity and flow rate in the chamber, and leaf temperature were maintained at $1600 \mu \mathrm{mol} \mathrm{m} \mathrm{s}^{-1}, 60 \%$ to $70 \%, 500 \mu \mathrm{mol} \mathrm{s}^{-1}$, and $30{ }^{\circ} \mathrm{C}$, respectively.

Light response curves were obtained from 9 a.m. to 11 a.m. The concentration of $\mathrm{CO}_{2}$, relative humidity and flow rate in the chamber, and leaf temperature were maintained at $400 \mathrm{ppm}, 60 \%$ to $70 \%, 500 \mu \mathrm{mol} \mathrm{s}{ }^{-1}$ and $30{ }^{\circ} \mathrm{C}$, respectively. From $200 \mu \mathrm{mol} \mathrm{m} \mathrm{m}^{-2} \mathrm{~s}^{-1}$ to $0 \mu \mathrm{mol} \mathrm{m}^{-2} \mathrm{~s}^{-1}$, the photosynthetic photon flux density (PPFD) was decreased to $50 \mu \mathrm{mol} \mathrm{m} \mathrm{m}^{-2} \mathrm{~s}^{-1}$. The AQY of photosynthesis were determined as the slopes of the photosynthesis light response curves.

Ten plants with similar growth vigor were harvested as samples by using a sickle for each plot. Spikes $\mathrm{m}^{-2}$, Kernels spike ${ }^{-1}, 1000$-kernels weight, and grain yield were also measured. A total of $2 \mathrm{~m}^{2}$ summer maize was harvested to measure yield.

The experimental data were analyzed by ANOVA and the treatment means were compared using LSD $(\mathrm{p} \leq 0.05)$.

\section{RESULTS AND DISCUSSION}

\section{Winter wheat stem number}

Obvious differences in the wheat stem number were observed between the different row spacing patterns, and the trend between the irrigated and rainfed treatments was similar (Figure 2). Irrigation and row spacing had significant effects on the growth of single plants. The stem number of SRPP at GS28 and GS32 was greatest during the growing season. On the other hand, the highest stem number was observed at GS32 and GS35 in DRPP. The stem number under irrigated conditions was larger than those under rainfed conditions from GS32 to GS80, but there was no significant difference between irrigated and rainfed conditions. We ranked the stem number of the different treatments in the following order: DRPP-I $>$ DRPP$\mathrm{R}>$ SRPP-I > DRPP-R. In general, the stem numbers of DRPP were higher than those of SRPP. The results revealed that a reasonable stem tiller number is helpful to build an appropriate group structure, which is the basis of the allocation of resources, including water, light and fertilizer. Irrigation had no obvious effect on the winter wheat stem number, because irrigation was applied at the time of stem elongation. The observed differences in stem number during the growing season were caused by the planting pattern. Therefore, the 
influence of row spacing on the tillers is greater than that of irrigation.

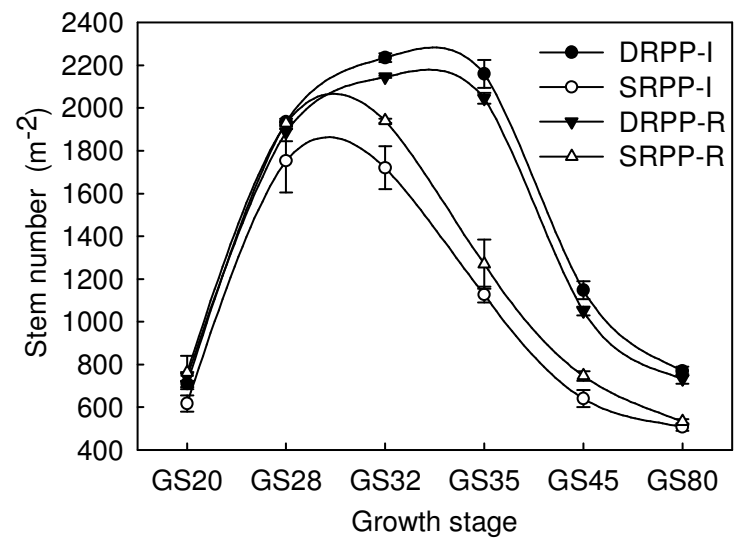

Figure 2. Plant stem number at different growth stages of the winter wheat. Values shown are the means over two years; the error bars represent the SE. SRPP, single row planting pattern; DRPP, double row planting pattern; I, irrigated; R, rainfed.

\section{Leaf area index}

LAI was measured after the flag leaf sheaths unfurled (Figure 3); the values are means of those values registered in the 2011-2012 and 2012-2013 growing seasons. The LAI of all treatments decreased with growth. There was no significant difference in the mean LAI value between DRPP and SRPP under the same growing conditions. The mean LAI under irrigated conditions was significantly higher than that of rainfed conditions for both DRPP and SRPP $(\mathrm{p} \leq 0.05)$. In other words, irrigation had a significant impact on LAI.

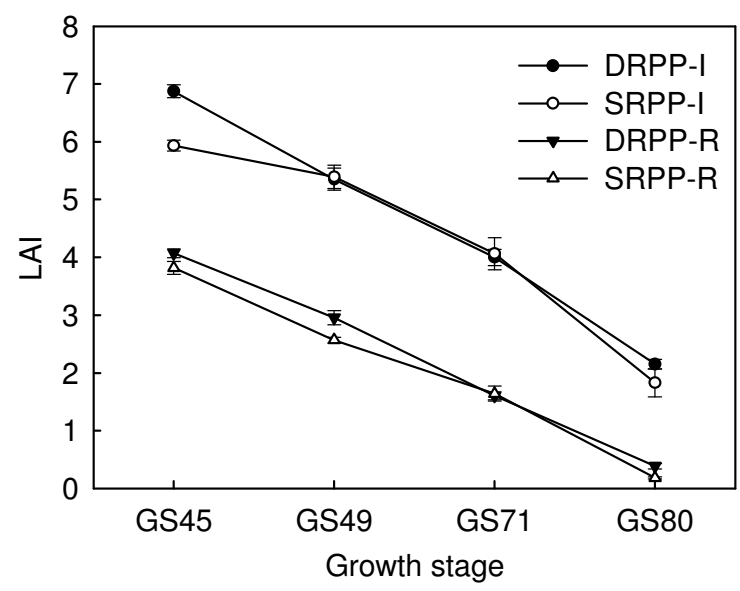

Figure 3. Leaf area index (LAI) at different growth stages of the winter wheat. The values shown are the means over two years; the error bars represent the SE. SRPP, single row planting pattern; DRPP, double row planting pattern; I, irrigated; R, rainfed.

\section{PAR capture ratio}

As growth occurred, the PAR capture ratio decreased, and the percentage of the PAR capture ratio at $50-120 \mathrm{~cm}$ above the ground increased for all treatments (Figure 4). In DRPP, the PAR capture ratio was significantly higher than that in SRPP under irrigated conditions $(\mathrm{p} \leq 0.05)$, but there was no significant difference between DRPP and SRPP under rainfed conditions $(p>0.05)$. Given the same growing conditions, the PAR capture ratios at $0-50$ $\mathrm{cm}$ were similar between the two planting patterns. Under irrigated conditions, at GS45, GS49, GS71, and GS80, PAR capture ratios in DRPP were 64.8\%, $65.9 \%, 53.6 \%$, and $48.6 \%$ higher than those under SRPP at 50-120 cm above the ground, respectively. Under rainfed conditions, the corresponding values were $32.0 \%, 51.4 \%, 14.8 \%$, and $15.4 \%$, respectively, all higher in DRPP than SRPP. These results imply that DRPP and irrigation both may improve the canopy light distribution. Wang et al. (2014) considered that the senescence of flag leaves resulted in a decreased grain filling rate and grain yield. Therefore, improving the PAR capture ratio in the canopy of wheat may have a crucial impact on 
the grain yield. These results indicated that increase the grain yield. improved planting patterns and irrigation could

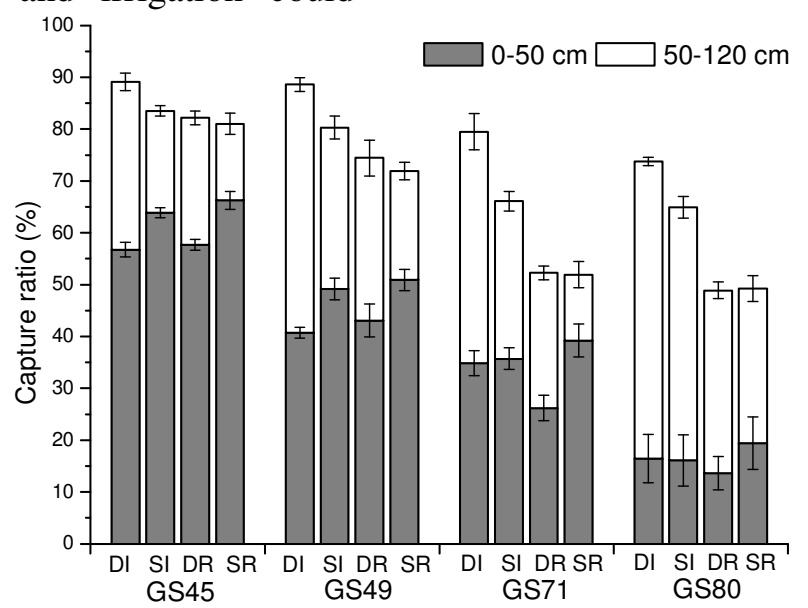

Figure 4. PAR capture ratio at different growth stages of the winter wheat. Values shown are the means over two years; the error bars represent the SE. D, double row planting pattern; S, single row planting pattern; I, irrigated; R, rainfed.

Net photosynthetic rate (Pn), intercellular $\mathrm{CO}_{2}$ concentration $(\mathrm{Ci})$, transpiration rate $(\mathrm{Tr})$, and $\mathrm{H}_{2} \mathrm{O}$ conductance (Cond)

At GS49 and GS71, Pn values in the flag leaves were similar for both DRPP and SRPP under irrigated conditions. However, under rainfed conditions, Pn values in DRPP were significantly higher than those in SRPP by $44.2 \%$ and $41.0 \%$, respectively ( $\mathrm{p} \leq 0.05$ ). From GS71 to GS80, photosynthetic rates decreased in both DRPP and SRPP. Under rainfed conditions, at GS80, Pn values in DRPP were significantly higher by $54.7 \%$ than those in SRPP $(p \leq 0.05)$. In terms of $\mathrm{Ci}$, there was no significant difference between DRPP and SRPP under the same growing conditions $(p>0.05)$. Under irrigated conditions, the photosynthetic rate declined from GS71 to GS80 while the $\mathrm{Ci}$ of the flag leaves remained constant. However, under rainfed conditions, the $\mathrm{Ci}$ of the flag leaves increased by $120.0 \%$ between these two stages (Figure 5). $\mathrm{Tr}$ and Cond of irrigation were significantly higher than those of rainfed plants $(\mathrm{p} \leq$ 0.05); $\operatorname{Tr}$ and Cond of DRPP were $51.1 \%$ and $36.1 \%$ higher than those of SRPP under rainfed conditions. Plants cultivated in the different patterns under the same planting density produced different dry matter amounts at the ripening stage (HAN et al., 2014). The dry matter accumulation is the ultimate product derived from the photosynthetic characteristics (MASONI et al., 2007). After GS49, the photosynthetic rate of flag leaves in DRPP was significantly higher than in SRPP under rainfed conditions. Thus, photosynthetic characteristics of DRPP showed an obvious advantage under rainfed conditions.

\section{Apparent quantum yields (AQY) of flag leaves}

The mean AQY of flag leaves under rainfed conditions was lower than that of irrigated conditions because of water stress (Figure 6). In SRPP, the AQY of flag leaves under rainfed conditions was $33.0 \%$ lower than under irrigated conditions. In DRPP, a difference of $23.6 \%$ was observed. The mean AQY of plants in DRPP was $7.9 \%$ higher than that in SRPP under irrigated conditions, but this difference was $23.0 \%$ under rainfed conditions. This observation indicates that DRPP under rainfed conditions had a higher AQY than under irrigated conditions.

\section{Grain yield and yield components}

The grain yields of DRPP were $6.7 \%$ (2011-2012) and 13.5\% (2012-2013) higher than those of SRPP under irrigated conditions. The spike number of DRPP were 22.8\% (2011-2012) and $25.5 \%$ (2012-2013) higher than those of SRPP, but the 1000-kernel weight were $1.4 \%$ (2011-2012) and 9.1\% (2012-2013) lower in DRPP than those of SRPP, respectively (Table 2). Meanwhile, under rainfed conditions, the kernel number per spike and 1000-kernel weight of DRPP were higher than that of SRPP in 2011-2012, and the kernel number per spike and 1000-kernel weight were not significantly different between SRPP and DRPP in 2012-2013 ( $p>0.05$ ). However, in 2011-2012 and 2012-2013, the spike numbers of DRPP were $6.9 \%$ and $22.8 \%$ higher than those of SRPP, and the grain yields were significantly higher (by $11.3 \%$ and $11.0 \%$ ) than that of SRPP, respectively $(\mathrm{p} \leq 0.05)$. 


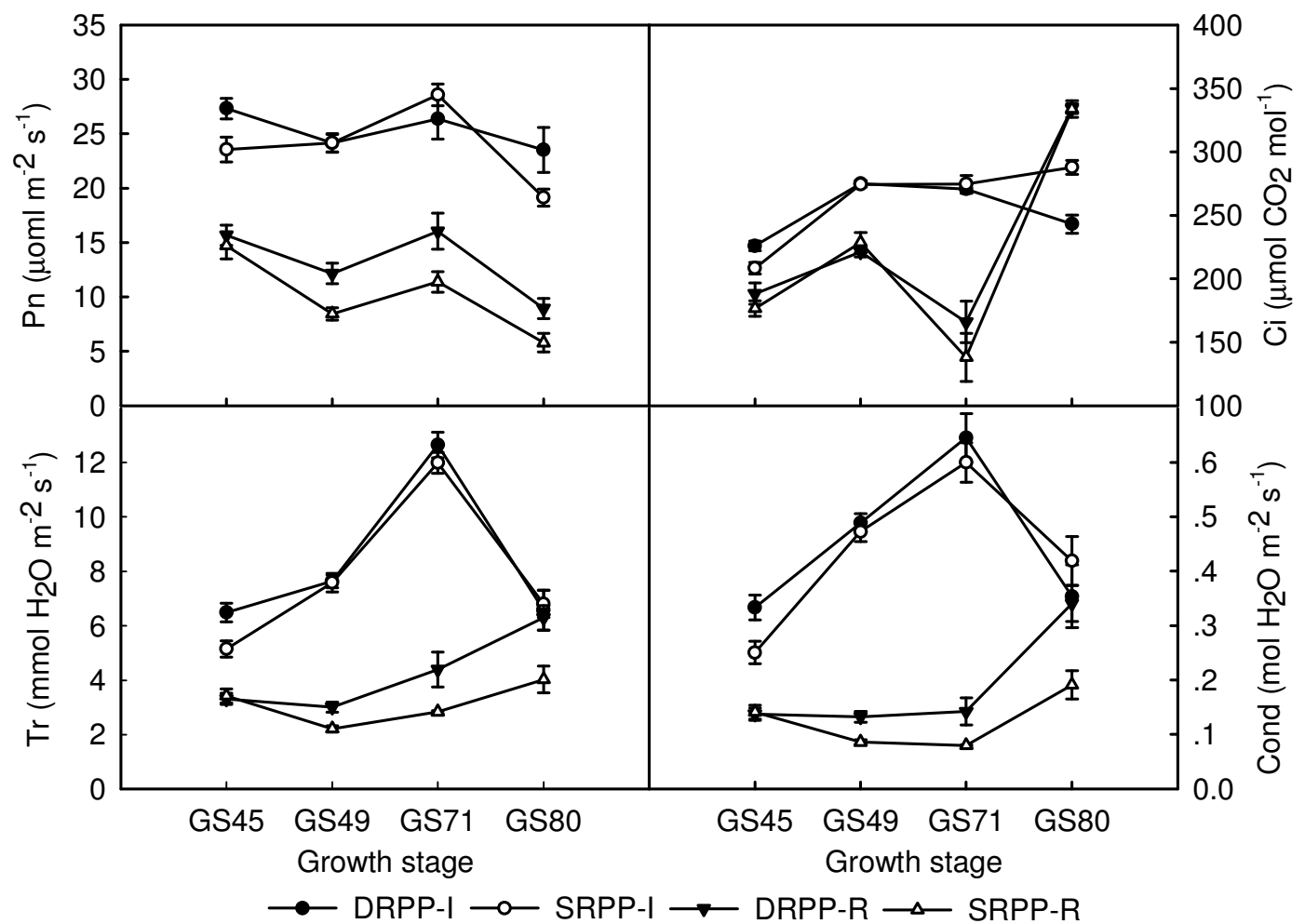

Figure 5. Net photosynthetic rate $(\mathrm{Pn})$, intercellular $\mathrm{CO}_{2}$ concentration $(\mathrm{Ci}), \mathrm{H}_{2} \mathrm{O}$ conductance $(\mathrm{Cond})$ and transpiration rate $(\mathrm{Tr})$ at different growth stages of the winter wheat. Values shown are means over two years; the error bars represent the SE. SRPP, single row planting pattern; DRPP, double row planting pattern; I, irrigated; R, rainfed.

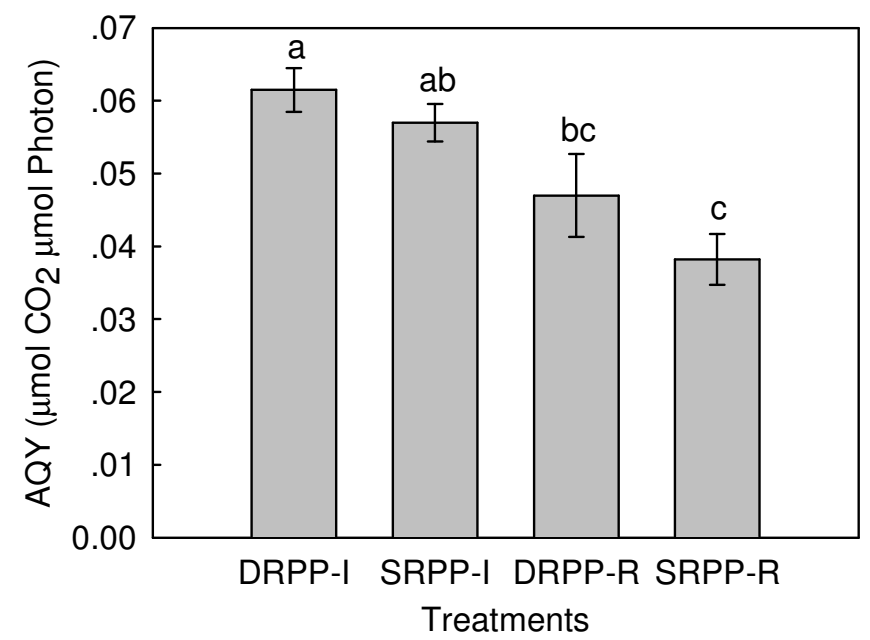

Figure 6. Apparent quantum yield (AQY) of flag leaves under irrigated (I) and rainfed (R) conditions. Values shown are means over two years; the error bars represent the SE. SRPP, single row planting pattern; DRPP, double row planting pattern. 
Table 2. Grain yield and yield components of double row planting pattern (DRPP) and single row planting pattern (SRPP) under different water conditions.

\begin{tabular}{|c|c|c|c|c|c|}
\hline Treatments & & $\begin{array}{l}\text { Spikes } \\
\left(\mathrm{m}^{-2}\right)\end{array}$ & $\begin{array}{l}\begin{array}{l}\text { Kernels } \\
\left(\text { spike }^{-1}\right)\end{array} \\
\end{array}$ & $\begin{array}{l}\text { 1000-kernel } \\
\text { weight }(\mathrm{g})\end{array}$ & $\begin{array}{l}\text { Grain yield } \\
\left(\mathrm{g} \mathrm{m}^{-2}\right)\end{array}$ \\
\hline \multicolumn{6}{|l|}{$2011-2012$} \\
\hline \multirow[t]{2}{*}{ Rainfed } & DRPP & $678 a$ & $28.7 \mathrm{a}$ & 35.4 & $703 a$ \\
\hline & SRPP & $634 \mathrm{~b}$ & $24.2 \mathrm{~b}$ & 34.1 & $632 b$ \\
\hline $\mathrm{LSD}_{0.05}$ & & 44 & 2.3 & NS & 29 \\
\hline \multirow[t]{2}{*}{ Irrigated } & DRPP & $641 a$ & 27.8 & 34.3 & $781 \mathrm{a}$ \\
\hline & SRPP & $522 b$ & 27.2 & 34.8 & $732 b$ \\
\hline \multicolumn{6}{|l|}{$\begin{array}{l}\text { LDD } 0.05 \\
2012-2013\end{array}$} \\
\hline \multirow[t]{2}{*}{ Rainfed } & DRPP & $693 a$ & 25.3 & 33.9 & $604 a$ \\
\hline & SRPP & $582 \mathrm{~b}$ & 24.5 & 32.9 & $544 \mathrm{~b}$ \\
\hline $\mathrm{LSD}_{0.05}$ & & 112 & NS & NS & 54 \\
\hline \multirow[t]{2}{*}{ Irrigated } & DRPP & $722 a$ & 26.5 & $37.8 b$ & $850 \mathrm{a}$ \\
\hline & SRPP & $575 b$ & 26.8 & $41.6 \mathrm{a}$ & $749 b$ \\
\hline $\mathrm{LSD}_{0.05}$ & & 97 & NS & 3.0 & 61 \\
\hline
\end{tabular}

Means with different letters in a column are significantly different $(\mathrm{p} \leq 0.05)$

\section{CONCLUSIONS}

The double-row planting pattern was better than the single-row planting pattern in terms of all traits.

The double-row planting pattern increased the photosynthetic active radiation capture ratio at $50-120 \mathrm{~cm}$ above the ground, the photosynthetic rate, the transpiration rate, the $\mathrm{H}_{2} \mathrm{O}$ conductance, the apparent quantum yield, the grain yield, and the yield components under rainfed conditions.

These results suggest that the double-row planting pattern can be extended to improve the wheat yield in the drought-prone areas of Northern China.

\section{ACKNOWLEDGMENTS}

The research was supported by the National High Technology Research and Development Program of China Project (2013AA102903), Guangxi Natural Science Foundation (2015GXNSFAA139049) and Starting Foundation for Doctors of Guangxi University (XBZ160072).

RESUMO: O trigo de inverno (Triticum aestivum) é cultivado em uma vasta região; no entanto, a água é escassa durante a estação de crescimento do trigo na Planície do Norte da China. Assim, o trigo de inverno deve ser irrigado para manter um rendimento de grãos estável e elevado. O objetivo deste trabalho de campo foi o de desenvolver um padrão de plantação de precisão que conserve a água para o trigo de inverno que é cultivado na Planície do Norte da China com o propósito de explorar os benefícios da retenção de água e os efeitos na produtividade do trigo. Para isso, diversas variáveis de produção e índices fotossintéticos foram medidos, incluindo o número de hastes, o índice de área da folha (do inglês, LAI - leaf area index), a radiação fotossinteticamente disponível (do inglês, PAR - photosynthetically available radiation), taxa fotossintética líquida e o rendimento de grãos. O estudo foi conduzido durante as estações de crescimento do trigo de inverno em 2011-2012 e 2012-2013. O experimento incluiu um padrão de plantação em fila dupla (do inglês, DRPP double-row planting pattern) e um padrão de plantação em fila única (do inglês, SRPP - single-row planting pattern), em ambos os casos ou foram irrigados artificialmente ou através da chuva (regadio e sequeiro). A área de cada lote de terra foi de $9 \mathrm{~m} 2$, e o delineamento experimental foi um de blocos aleatórios com três repetições. Todos os resultados foram analisados com uma ANOVA, um teste F, e um LSD $(\mathrm{p} \leq 0.05)$ para a comparação das médias. As taxas de captura de PAR no DRPP foram maiores do que aquelas no SRPP a 50-120 cm acima do solo. As características fotossintéticas das folhas-bandeira (do inglês, flag leaves) sob condições de irrigação artificial não foram significativamente influenciadas pelo respectivo padrão de plantação. No entanto, num estágio de crescimento de $80 \%$ abaixo das condições de irrigação pela chuva, a taxa fotossintética média dentre as folhas-bandeira no DRPP foi maior que aquela observada no SRPP. Além disso, o DRPP sob condições de irrigação pela chuva foi mais suscetível ao aumento do rendimento quântico aparente (do inglês, AQY - apparent quantum yield) das folhas-bandeira do que o rendimento obtido através da irrigação artificial. Estes resultados sugerem que o DRPP otimiza a distribuição PAR do dossel no trigo de inverno e contribui para a manutenção de uma maior capacidade fotossintética nas folhas bandeira sob estresse hídrico (a condição de sequeiro). Esta relação pode ser aplicada em ensaios de demonstração para encorajar os agricultores de trigo de inverno a incorporar o uso 
do DRPP em áreas propensas à seca, que estão submetidas a precipitação insuficiente durante a fase de crescimento do trigo no Norte da China.

PALAVRAS-CHAVE: Triticum aestivum. Taxa de captura da radiação ativa fotossintética (PAR). Taxa fotossintética líquida. Índice de área foliar. Componentes de rendimento.

\section{REFERENCES}

ACRECHE, M. M.; BRICEÑO-FÉLIX, G.; SÁNCHEZ, J. A. M.; SLAFER, G. A. Radiation interception and use efficiency as affected by breeding in Mediterranean wheat. Field Crops Research, v. 110, p. 91-97, 2009. https://doi.org/10.1016/j.fcr.2008.07.005

AVOLA, G.; TUTTOBENE, R.; GRESTA, F.; ABBATE, V. Weed control strategies for grain legumes. Agronomy for Sustainable Development, v. 28, p. 389-395, 2008. https://doi.org/10.1051/agro:2008019

BRANT, V.; NECKÁŘ, K.; PIVEC, J.; DUCHOSLAV, M.; HOLEC, J.; FUKSA P.; VENCLOVÁ, V. Competition of some summer catch crops and volunteer cereals in the areas with limited precipitation. Plant, Soil and Environment, v. 55, p. 17-24, 2009.

DE BRUIN, J. L.; PEDERSEN, P. Effect of row spacing and seeding rate on soybean yield. Agronomy Journal, v. 100, p. 704-710, 2008. https://doi.org/10.2134/agronj2007.0106

DENG, X. P.; SHAN, L.; ZHANG H.; TURNER, N. C. Improving agricultural water use efficiency in arid and semiarid areas of China. Agricultural Water Management, v. 80, p. 23-40, 2006.

https://doi.org/10.1016/j.agwat.2005.07.021

DONG, B. D.; SHI, L.; SHI, C. H.; QIAO, Y. Z.; LIU, M. Y.; ZHANG, Z. B. Grain yield and water use efficiency of two types of winter wheat cultivars under different water regimes. Agricultural Water Management, v. 99, p. 103-110, 2011. https://doi.org/10.1016/j.agwat.2011.07.013

FENG, Z. B.; WANG, X. Y.; ZHOU, X. B.; CHEN, Y. H.; BI, J. J. Effects of planting patterns and irrigation conditions on the photosynthetic characteristics of winter wheat. Journal of Animal and Plant Sciences, v. 24, p. 897-903, 2014.

GITELSON, A. A.; PENG, Y.; ARKEBAUER, T. J.; SUYKERA, A. E. Productivity, absorbed photosynthetically active radiation, and light use efficiency in crops: Implications for remote sensing of crop primary production. Journal of Plant Physiology, v. 177, p. 100-109, 2015.

https://doi.org/10.1016/j.jplph.2014.12.015

HAN, Y. Y.; WANG, G. Y.; ZHOU, X. B.; CHEN,Y. H.; LIU, P. Radiation use efficiency and yield response of winter wheat to planting patterns and irrigation in northern China. Agronomy Journal, v. 106, p. 168-174, 2014. https://doi.org/10.2134/agronj2013.0252

LACK, S. H.; DASHTI, H.; ABADOOZ, G. H.; MODHEJ, A. Effect of different level of irrigation and planting pattern on grain yield components and water use efficiency of corn grain (Zea may L) hybrid SC. 704. African Journal of Agricultural Research, v. 7, p. 2873-2878, 2012. 
LIU, Z.; CHENG, R.; XIAO, W.; GUO, Q.; WANG, Y.; WANG, N.; WANG, Y. Leaf gas exchange, chlorophyll fluorescence, non-structural carbohydrate content and growth responses of Distylium chinense during complete submergence and subaerial re-emergence. Aquatic Botany, v. 124, p. 70-77, 2015. https://doi.org/10.1016/j.aquabot.2015.04.003

MASONI, A.; ERCOLI, L.; MARIOTTI, M.; ARDUINI, I. Post-anthesis accumulation and remobilization of dry matter, nitrogen and phosphorus in durum wheat as affected by soil type. European Journal of Agronomy, V. 26, p. 179-186, 2007. https://doi.org/10.1016/j.eja.2006.09.006

MATTERA, J.; ROMERO, L. A.; CUATRÍN, A. L.; CORNAGLIA, P. S.; GRIMOLDI, A. A. Yield components, light interception and radiation use efficiency of Lucerne (Medicago sativa L.) in response to row spacing. European Journal of Agronomy, v. 45, p. 87-95, 2013. https://doi.org/10.1016/j.eja.2012.10.008

NAYYAR H.; GUPTA, D. Differential sensitivity of C3 and C4 plants to water deficit stress: Association with oxidative stress and antioxidants. Environmental and Experimental Botany, v. 58, p. 106-113, 2006. https://doi.org/10.1016/j.envexpbot.2005.06.021

PANDA, D.; SHARMA, S. G.; SARKAR, R. K. Chlorophyll fluorescence parameters, $\mathrm{CO}_{2}$ photosynthetic rate and regeneration capacity as a result of complete submergence and subsequent re-emergence in rice (Oryza sativa L.). Aquatic Botany, v. 88, p. 127-133, 2008. https://doi.org/10.1016/j.aquabot.2007.08.012

RAMPINO, P.; PATALEO, S.; GERARDI, C.; MITA G.; PERROTTA, C. Drought stress response in wheat physiological and molecular analysis of resistant and sensitive genotypes. Plant and Cell Environment, v. 29, p. 2143-2152, 2006. https://doi.org/10.1111/j.1365-3040.2006.01588.x

SACKS, W. J., DERYNG, D.; FOLEY, J. A.; RAMANKUTTY, N. Crop planting dates: An analysis of global patterns. Global Ecology and Biogeography, V. 19, p. 607-620, 2010. https://doi.org/10.1111/j.14668238.2010.00551.x

SAN-OH, Y.; SUGIYAMA, T.; YOSHITA, D.; OOKAWA T.; HIRASAWA, T. The effect of planting pattern on the rate of photosynthesis and related processes during ripening in rice plants. Field Crops Research, v. 96, p. 113-124, 2006. https://doi.org/10.1016/j.fcr.2005.06.002

WANG, Y.; ZHANG, J.; YU, J.; JIANG, X.; SUN, L.; WU, M.; CHEN, G.; LV, C. Photosynthetic changes of flag leaves during senescence stage in super high-yield hybrid rice LYPJ grown in field condition. Plant Physiology and Biochemistry, V. 82, p. 194-201, 2014. https://doi.org/10.1016/j.plaphy.2014.06.005

ZADOKS, J. C.; CHANG, T. T.; KONZAK, C. F. A decimal code for the growth stages of cereals. Weed Research, v. 14, p. 415-421, 1974. https://doi.org/10.1111/j.1365-3180.1974.tb01084.x

ZHOU, X. B.; CHEN Y. H.; OUYANG, Z. Spacing between rows: effects on water-use efficiency of doublecropped wheat and soybean. Journal of Agricultural Science, Cambridge, v. 153, p. 90-101, 2015. https://doi.org/10.1017/S0021859613000890 